\title{
ANALISA KUALITAS LAYANAN BISNIS MAKANAN DAN MINUMAN DI SURABAYA DITINJAU DARI DERAJAT PEMENUHAN KEPUASAN KONSUMEN
}

\author{
Fransisca Andreani \\ Program Manajemen Perhotelan, Fakultas Ekonomi \\ Universitas Kristen Petra - Surabaya \\ Email: andrea@peter.petra.ac.id
}

\begin{abstract}
Food and beverages industries in Surabaya have grown in the last few years. Businessmen have tried hard to deliver the best service they have to their customers in order to satisfy them. This research is done to find out the service quality of food and beverages industries in Surabaya using a quantitative descriptive approach. Service quality is measured by comparing the actual service with the expected service to find Customer Satisfaction Index (CSI). CSI shows that food and beverages industries in Surabaya have already been able to deliver their best service quality to their customers. Hopefully this research is beneficial for the related industries because it can also serve as their feedback to understand their customers better and improve their service quality when needed.
\end{abstract}

Kaywords: service quality, Customer Satisfaction Index.

\section{PENDAHULUAN}

Pertumbuhan bisnis makanan dan minuman berkembang pesat di kota Surabaya beberapa tahun terakhir ini. Para pebisnis berusaha menampilkan suasana restoran/ cafe dengan dekor interior dan eksterior yang terbaik disamping menjual makanan dan minuman yang bervariasi dan berbeda dengan pesaing-pesaingnya. Namun makanan yang lezat dan minuman yang nikmat juga bukan merupakan jaminan atas kepuasan pelanggan tanpa didukung oleh kualitas layanan yang prima. Hal ini didukung oleh pernyataan Orilio (2005) yang menyatakan bahwa udang galah yang sangat lezat sekalipun akan terasa tidak enak jika layanan yang disampaikan tidak baik. Oleh karena itu penelitian ini dilakukan untuk mengetahui kualitas layanan dari bisnis makanan dan minuman di Surabaya.

Penelitian ini diharapkan mampu memberikan manfaat yang sangat besar bagi pelaku bisnis jasa makanan dan minuman untuk mengetahui sejauh mana mereka sudah mampu memberikan layanan seperti yang diharapkan oleh pelanggannya. Selain itu hasil penelitian ini diharapkan akan berguna sebagai feedback untuk meningkatkan kinerja layanan mereka dalam rangka memberikan kepuasan kepada pelanggannya.

\section{RUMUSAN MASALAH}

Bagaimanakah tingkat kepuasan pelanggan terhadap kualitas layanan bisnis makanan dan minuman (restoran dan cafe) di Surabaya?

\section{TINJAUAN PUSTAKA}

Kepuasan pelanggan merupakan hal yang penting dalam persaingan bisnis sekarang ini. Banyak perusahaan berusaha meningkatkan kualitas layanannya dalam usahanya untuk memenuhi harapan dan memuaskan para pelanggannya. Dengan kepuasan yang maksimal diharapkan pelanggan akan menjadi setia terhadap produk dan layanan yang dipasarkannya.

\section{Layanan (Service) dan Karakteristik Layanan}

Payne (1993, p.6), Kotler \& Keller (2006, p.372) menyatakan bahwa layanan adalah sebuah aktivitas yang diasosiasikan dengan elemen intangibility (sesuatu yang abstrak), dimana di dalamnya terjadi interaksi antara pelanggan dengan penyedia layanan tetapi tidak berakibat terhadap suatu kepemilikan. Perubahan kondisi dapat saja terjadi dan produksi layanan bisa saja berkaitan dengan sebuah produk fisik. Sedangkan Zeithaml \& Bitner (2003, p.3) berpendapat bahwa layanan, termasuk segala aktivitas ekonomi yang output nya bukan merupakan produk fisik, umumnya dikonsumsi dan diproduksi pada saat yang sama dan memberikan nilai tambah dalam berbagai bentuk (seperti kenyamanan, kesukaan, kegembiraan atau kesehatan) yang biasanya berkaitan dengan hal-hal tidak tampak/ abstrak bagi pembeli layanan.

Berdasarkan karakteristiknya, kebanyakan layanan mempunyai tiga karakteristik dasar (Gronroos, 2000, p.47) yang meliputi: 
1. Layanan adalah proses yang terdiri dari serangkaian aktivitas (bukan benda).

2. Untuk taraf tertentu, layanan diproduksi dan dikonsumsi secara simultan.

3. Untuk taraf tertentu, pelanggan ikut berpartisipasi dalam proses produksi layanan.

Sedangkan Zeithaml, Bitner \& Gremler (2009, pp. 20-22), dan Kotler \& Keller (2006, pp. 375-377) berpendapat bahwa layanan mempunyai empat karakteristik. Pertama, intangibility yaitu layanan tidak bisa dilihat, dirasakan seperti halnya ketika mengkonsumsi produk fisik sehingga tidak bisa disajikan dan dikomunikasikan setiap saat. Kedua heterogeneity/variability, yaitu layanan diproduksi oleh manusia sehingga tidak mungkin ada dua buah layanan yang persis sama karena masing-masing mempunyai permintaan dan pengalaman layanan yang unik. Ketiga, simultaneous production and consumption/inseparability yaitu kebanyakan layanan dijual lebih dulu baru kemudian diproduksi dan dikonsumsi secara simultan pada saat yang bersamaan. Pada saat aktivitas ini berlangsung ada interaksi langsung antara penyedia layanan dan pembeli layanan. Keempat, perishable yaitu layanan tidak dapat disimpan, dijual kembali atau dikembalikan seperti semula.

\section{Kualitas Layanan (Quality of Service)}

Ada beberapa pendapat mengenai kualitas layanan (quality of service). Kualitas layanan merupakan evaluasi kognitif jangka panjang dari pelanggan terhadap penyampaian layanan dari suatu perusahaan (Lovelock \& Wright, 2002, p. 87). Sedangkan Sureshchandar, Rajendran \& Anantharaman (2002) yang mengutip pernyataan Parasuraman et al. (1988), Zeithaml (1988), Bitner et al. (1990), Bolton \& Drew (1991 a, b), Cronin \& Taylor (1992), Bitner \& Hubert (1994) mengatakan bahwa kualitas layanan adalah semacam sikap - keseluruhan evaluasi, dan keduanya (kualitas layanan dan sikap) tersebut dipandang serupa.

Sedangkan Lovelock \& Wright (2002, pp. 266267), Zeithaml \& Bitner (2003, p. 93) menyatakan dimensi kualitas layanan berdasarkan riset ada lima, yang disebut juga dengan SERVQUAL SCALE, yaitu:

1. Reliability: kemampuan untuk menyediakan layanan yang dijanjikan secara mandiri dan tepat.

2. Responsiveness: keinginan untuk membantu pelanggan dan menyediakan layanan yang tepat.

3. Assurance: pengetahuan dan keramahtamahan staff/karyawan serta kemampuan mereka untuk dapat dipercaya.
4. Emphaty: peduli dan perhatian pada setiap pelanggan.

5. Tangibles: penampilan fisik dari fasilitas, peralatan, staff/karyawan dan materi tertulis dari perusahaan.

Berdasarkan kelima dimensi kualitas layanan, Lovelock \& Wright (2002, pp.2 77), Zeithaml \& Bitner (2003, pp. 135), menyatakan ada 21 atribut layanan (SERVQUAL attributes). Tetapi atribut layanan ini tidak selalu sesuai dan mempunyai arti yang sama untuk setiap industri layanan (Arnould, Price and Zinkhan, 2002, p. 619). Sebagai contoh employee responsiveness atau service reliability mempunyai arti yang berbeda pada industri layanan yang berbeda. Seorang staff hotel yang menjawab telpon dengan cepat bisa diartikan sebagai sikap yang terlalu responsif oleh pelanggan; dan kehandalan layanan bagi pelanggan hotel bisa diartikan kemampuannya dalam mengatasi masalah kerusakan AC di kamar. Gronroos (2000, p. 78) menambahkan bahwa untuk mengukur kualitas layanan yang terbaik dan tepat sebaiknya digunakan pendekatan atribut layanan yang sesuai dengan apa yang dialami dan diinginkan oleh pelanggan. Oleh karena itu perusahaan perlu memahami atribut layanan yang relevan dengan pelanggannya.

\section{Peran Staff/Karyawan Dalam Menyampaikan Layanan}

Menurut Hartline, Maxham \& McKey (2000), yang mengutip pernyataan Parasuraman, Zeithaml \& Berry (1985), dalam banyak kasus karyawan yang langsung berhubungan dengan pelanggan merupakan wakil dari perusahaan layanan sehingga pelanggan akan memperoleh kesan yang mendalam dari proses interaksi langsung itu. Seorang service executive/ supervisor mengatakan bahwa service employess (karyawan yang melayani) adalah sangat penting dalam membentuk tingkat kualitas layanan yang diperoleh pelanggan.

Karyawan, baik yang berada di garis depan atau melakukan kontak langsung dengan pelanggan maupun yang mendukung aktivitas layanan dari belakang layar, adalah sangat penting bagi kesuksesan industri layanan. Mereka adalah para aktor yang berperan dalam menyampaikan layanan yang dapat mempengaruhi persepsi pembeli, utamanya mereka yang berada di garis depan sebagai service employees. Service employees mempunyai peranan sebagai the service, organization in the customer's eyes, brand, marketers (Zeithaml, Bitner \& Gremler, 2009, p. 352). 
Peran pertama adalah "Service employees are the service." Karyawan adalah setara dengan layanan. Mereka memproduksi/menyediakan dan menyampaikan layanan secara langsung pada pelanggan. Kedua yaitu "Service employess are the organization in the customer's eyes." Dalam pandangan pelanggan, keberadaan mereka (baik yang bekerja sebagai resepsionis maupun pelayan restoran) adalah sebagai wakil dari perusahaan sehingga apa yang mereka katakan dan kerjakan dapat mempengaruhi persepsi perusahaan. Ketiga adalah "Service employees are the brand." Sekalipun mereka sedang tidak bertugas atau tengah beristirahat, mereka adalah cerminan perusahaan. Jika mereka tidak profesional, misalnya bertindak kasar dan seenaknya terhadap pelanggan, maka citra perusahaan akan menjadi buruk sekalipun hal itu dilakukan ketika mereka tidak bertugas. Keempat yaitu "Service employees are marketers." Mereka adalah wakil dari perusahaan yang berfungsi sebagai pemasar sehingga mereka dapat mempengaruhi kepuasan pelanggan.

Lovelock \& Wirtz (2004, p. 310) menambahkan bahwa frontline staffs/ service employees mempunyai peranan yang sangat penting dalam mengantisipasi kebutuhan-kebutuhan pelanggan, menyesuaikan penyampaian layanan, dan membangun hubungan interpersonal dengan pelanggannya sehingga dapat meningkatkan kesetiaan pelanggan (customer loyalty). Sedapat mungkin service employees dapat membaca keinginan dan kebutuhan pelanggan yang tidak disampaikan secara verbal sehingga kepuasan mereka dapat melebihi harapannya.

Dalam persaingan bisnis sekarang ini, layanan merupakan hal yang paling penting bagi perusahaan untuk strategi diferensiasi ketika mereka menjual produk yang sama. Layanan yang baik akan menyelamatkan makanan yang tak enak. Sebaliknya hidangan utama yang lezat tidak menjamin dan dapat menyelamatkan layanan yang buruk (Orilio, 2005). Lebih lanjut Orilio menambahkan bahwa layanan harus dikelola terus menerus. Orang yang paling penting dalam perusahaan adalah mereka yang menyediakan dan menyampaikan layanan. J.W. Marriott Jr. mengatakan "Service people are the most important ones in the organization. Without them there is no product, no sale and no profit. Indeed, they are the product. Service is and should be a high calling." Kutipan ini berarti bahwa karyawan yang menyediakan layanan adalah orang yang paling penting dalam suatu organisasi. Tanpa mereka tidak ada produk, penjualan dan keuntungan. Sesungguhnya mereka adalah produk itu sendiri dan layanan adalah apa yang mereka sampaikan.

\section{Ukuran Kualitas Layanan}

Perusahaan perlu mengenali apa yang diharapkan dan diinginkan oleh pelanggan karena dua alasan. Pertama, perusahaan akan mengetahui secara lebih baik bagaimana definisi pelanggan tentang kualitas produk atau layanan. Kedua, perusahaan dapat memfasilitasi peningkatan kepuasan pelanggan melalui kuesioner (Hayes, 1997, p. 7). Pelanggan yang puas dengan kualitas layanan akan melakukan pembelian ulang dan merekomendasikan apa yang sudah diperoleh kepada orang lain melalui mulut ke mulut (word-of-mouth recommendations). Sebaliknya pelanggan yang tidak puas dengan kualitas layanan akan membuat yang bersangkutan tidak melakukan pembelian di masa datang atau berpindah ke produk dan layanan lain. Akibat yang lebih buruk lagi adalah jika dia menceritakan hal ini pada orang lain sehingga dapat mempengaruhi dan merusak citra produk atau layanan.

Kotler \& Keller (2006, p. 382) menambahkan bahwa pelanggan membentuk harapan akan layanan dari berbagai sumber seperti: pengalaman masa lalu, words of mouth (dari mulut ke mulut), dan iklan. Secara umum, pelanggan membandingkan layanan yang diperoleh dengan layanan yang diharapkan. Jika layanan yang diperoleh tidak sesuai dengan yang diharapkan, pelanggan akan menjadi kecewa. Jika layanan yang diperoleh sesuai atau melebihi yang diharapkan, mereka cenderung untuk menggunakan penyedia layanan itu lagi. Perusahaan-perusahaan yang berhasil adalah perusahaan yang mampu mengelola layanan sebagai penawaran yang berfungsi tidak hanya memuaskan pelanggan tetapi juga membuat mereka senang. Menyenangkan pelanggan berarti memberikan layanan yang melebihi harapan mereka.

Kualitas layanan dapat diukur dengan beberapa cara. Salah satunya dengan Importance-Performance Analysis (IPA). Menurut para peneliti, teknik ini sederhana, mudah diaplikasikan serta mempunyai nilai diagnosis. IPA merupakan alat untuk mengukur bukan hanya kinerja (performance) tetapi juga pentingnya (importance) kualitas layanan menurut penilaian pelanggan berdasarkan berbagai atribut/ dimensi layanan yang sesuai. Importance merujuk pada nilai relatif terhadap atribut layanan yang dianggap penting oleh pelanggan. Informasi tambahan inilah yang membuat analisis ini lebih cocok untuk meningkatkan kualitas layanan seperti yang diharapkan pelanggan. Tujuan IPA adalah untuk mengetahui atribut layanan mana atau kombinasi atribut layanan mana yang lebih berpengaruh atau tidak berpengaruh dalam pembelian ulang atau 
pemberian rekomendasi pada yang lain. Selain itu IPA juga bertujuan untuk mengetahui atribut layanan mana yang harus tetap dikelola dan dipertahankan (O’Neill \& Palmer, 2004).

Oleh Zeithaml, Bitner \& Gremler (2009, pp. 164-165), Kotler \& Keller (2006, pp. 388-389), IPA dengan 14 atribut layanan yang terbagi dalam 4 kuadran seperti Gambar 1.

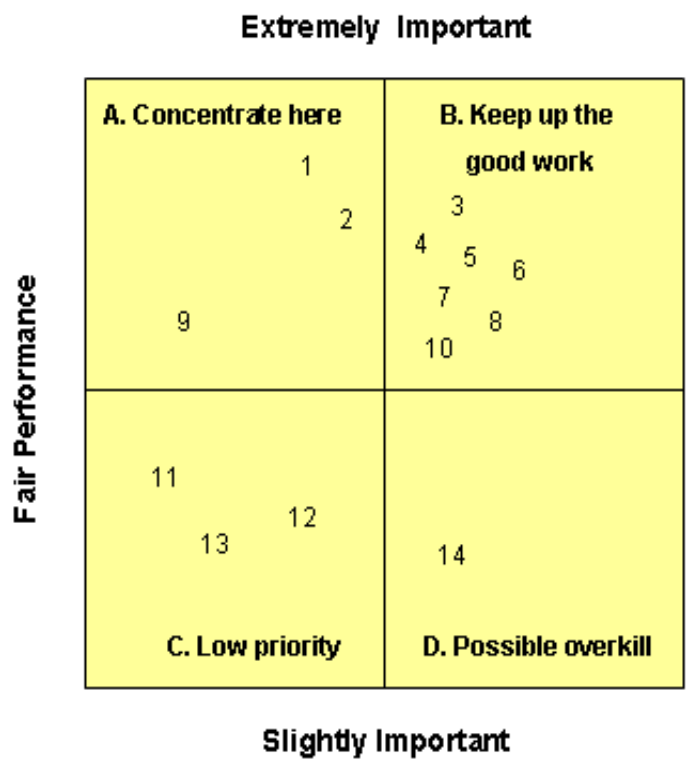

Sumber: Kotler \& Keller (2006, p.388)

\section{Gambar 1. Importance-Performance Analysis}

Kuadran A menunjukkan atribut layanan penting yang tidak disampaikan seperti yang diharapkan, diantaranya atribut 1,2 , dan 9. Atribut layanan ini perlu ditingkatkan lagi. Kuadran B menunjukkan atribut layanan penting yang sudah disampaikan dengan baik. Oleh karena itu perusahaan perlu tetap mengelola atribut layanan ini $(3,4,5,6,7$, 8 dan 10) dengan baik dan konsisten. Sedangkan kuadran C menunjukkan atribut layanan yang tidak begitu penting tetapi sudah cukup disampaikan dan tidak memerlukan perhatian lagi. Kuadran D menunjukkan atribut layanan yang tidak begitu penting tetapi sudah disampaikan dengan sangat baik sekali. Oleh karena itu perusahaan perlu meminimalisasi bagian ini untuk meningkatkan atribut layanan lain yang seharusnya disampaikan lebih baik lagi.

Importance-Performance Analysis (IPA) merupakan salah satu alat analisis yang penting untuk mengetahui kualitas layanan suatu industri. Ford \& Joseph (1999) menyatakan bahwa IPA dapat digunakan untuk mengetahui kualitas layanan tidak hanya di bidang pendidikan tetapi juga di industri perhotelan, restoran, rumah sakit, dan penyedia layanan kesehatan lainnya (O’Neill \& Palmer, 2004). Atribut yang dianggap penting oleh pelanggan (importance) ini selanjutnya disebut expexted service, sedangkan atribut yang mampu disampaikan oleh karyawan (performance) disebut sebagai actual service.

\section{METODE PENELITIAN}

Penelitian ini merupakan penelitian kuantitatif deskriptif yang bertujuan untuk mengetahui bagaimana tingkat kualitas layanan yang disampaikan oleh pelaku bisnis jasa makanan dan minuman yang ada di Surabaya kepada pelanggannya. Penelitian deskriptif adalah penelitian yang digunakan untuk mengetahui nilai atribut secara mandiri, baik satu atau lebih, tanpa membuat perbandingan atau menghubungkannya dengan elemen lain. Biasanya penelitian ini digunakan untuk menjawab pertanyaan "bagaimana" (Sugiyono, 2004, p.11 \& 31-32). Statisttik deskriptif yang digunakan dalam penelitian ini adalah frekuensi, modus, mean dan standard deviation untuk mengukur antara harapan responden dan kepuasan responden terhadap kualitas layanan dari restoran dan cafe di Surabaya.

Populasi dalam penelitian ini adalah seluruh pengunjung/ pelanggan restoran dan cafe yang ada di Surabaya. Mengingat tidak semua restoran maupun cafe yang ada di Surabaya mau berpartisipasi dalam penelitian ini serta adanya keterbatasan dana dan waktu, maka penelitian ini menggunakan non probability sampling dengan teknik convenience sampling dan quota sampling. Sampel dari penelitian ini adalah para pengunjung dari setiap restoran dan cafe yang bersedia berpartisipasi, dimana untuk setiap restoran hanya disebarkan sebanyak 50 kuesioner.

Penelitian dilakukan dalam dua tahap. Tahap pertama dilakukan dengan menyebarkan 2000 kuesioner pada bulan Maret sampai dengan awal April 2010 untuk mengetahui nama-nama restoran/ cafe yang pertama kali diingat oleh pelanggan atau yang menjadi Top of Mind. Dengan tingkat responsi sebesar 99,8\% diperoleh 50 nama restoran/cafe. Dari 50 restoran/cafe yang dihubungi hanya ada 28 restoran dan cafe yang bersedia diteliti kualitas layanannya.

Pada tahap kedua, penelitian dilakukan pada akhir April - awal Juni 2010 dengan menyebarkan kuesioner terhadap 50-55 orang pengunjung yang dijumpai sedang makan di restoran atau cafe yang diteliti. Agar hasil penelitian tidak bias, tim peneliti melakukan kontrol terhadap komposisi responden, khususnya kontrol terhadap jenis kelamin, usia dan pekerjaan responden yang diusahakan seimbang 
antara kelompok yang satu dengan yang lainnya, sehingga tidak ada satu kelompok pun yang menonjol. Kuesioner diberikan kepada pelanggan/ pengunjung restoran yang telah selesai makan dan masih menunggu proses penyelesaian pembayaran (billing) serta bersedia mengisi kuesioner. Tim pencacah selalu mendampingi pelanggan/pengunjung yang mengisi kuesioner. Total responden yang terlibat dalam penelitian ini ada sebanyak 1358 responden. Sedangkan tingkat responsinya sebesar $98,4 \%$ karena kuesioner yang valid untuk diolah ada 1337 lembar.

Pengukuran kualitas layanan dilakukan dengan membandingkan actual service dengan expected service. Yang dimaksud expected service adalah harapan pelanggan terhadap kualitas layanan sebelum mereka dilayani. Sedangkan actual service adalah persepsi pelanggan terhadap kualitas layanan setelah mereka dilayani. Pada penelitian ini derajat pemenuhan kepuasan pelanggan disebut juga dengan Customer Satisfaction Index (CSI). Apabila nilai CSI yang diperoleh adalah 1 (satu) maka pelanggan merasa puas karena kualitas layanan yang diterima sudah sesuai dengan yang diharapkan. Sedangkan apabila derajat pemenuhan kepuasannya lebih dari 1 (satu), maka dikatakan pelanggan merasa sangat puas karena kualitas layanan yang diterima melebihi dari apa yang diharapkan.

Apabila layanan yang diterima oleh pelanggan melebihi layanan yang diharapkan oleh mereka, maka yang terjadi adalah pelanggan tidak hanya puas, namun pelanggan sudah delighted. Dengan demikian, indeks kepuasan yang dilihat bukan lagi CSI, melainkan CDI (Customer Delighted Index). CDI diperoleh apabila CSI lebih besar daripada 1.00 (melebihi 100\%). Hal ini nampak pada Gambar 2.

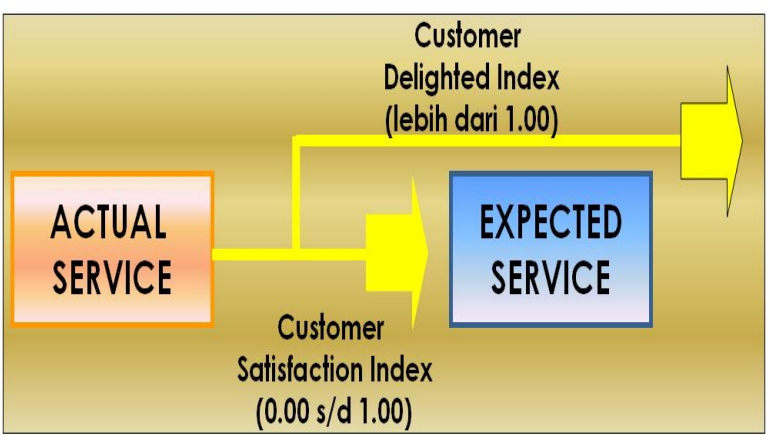

\section{Gambar 2. CSI dan CDI}

Kualitas layanan yang diukur dalam penelitian ini meliputi lima dimensi kualitas layanan yang terdiri dari 18 atribut layanan. Secara keseluruhan rinciannya adalah sebagai berikut:
1. Bukti fisik (tangible) merupakan tampilan fisik yang berupa fasilitas, peralatan, staf, dan materi komunikasi dari restoran dan cafe yang dapat dilihat. Fasilitas fisik kemudian dibagi menjadi 8 atribut layanan antara lain: disain interior/dekorasi restoran/cafe, penataan fasilitas dan peralatan restoran/cafe, kebersihan restoran/cafe, penyajian makanan dan minuman (food appearance), rasa makanan dan minuman, penampilan (grooming) staf, ketersediaan buku menu yang informatif, ketersediaan fasilitas dan layanan pendukung lainnya

2. Keterandalan (reliability) menunjukkan kemampuan pihak restoran dan café menyampaikan jasa secara tepat dan akurat kepada pelanggan seperti yang dijanjikan sebelumnya. Dimensi keterandalan dibagi menjadi 3 atribut layanan yang meliputi ketepatan penyajian makanan dan minuman, layanan tepat waktu, konsistensi layanan

3. Empati (empathy) merupakan perhatian staf secara individu atau personal kepada pelanggan. Dimensi empati dibagi menjadi 2 atribut layanan yaitu kesediaan staf membantu, perhatian personal staf kepada pengunjung.

4. Kecepat-tanggapan (responsiveness) merupakan kesediaan staf untuk membantu pelanggan pelanggan dan memberikan layanan dengan cepat bagi mereka. Dimensi kecepat-tanggapan dibagi menjadi 2 atribut layanan yaitu kecepatan layanan dan keramahan staf.

5. Jaminan (assurance) merupakan pengetahuan dan kesopanan yang dimiliki oleh staf restoran dan cafe, serta kemampuan mereka untuk menumbuhkan kepercayaan dan keyakinan pelanggan bahwa layanan yang disampaikan adalah layanan yang berkualitas. Dimensi jaminan dibagi menjadi 3 atribut layanan yaitu product knowledge, kemampuan staf menjawab pertanyaan \& menangani keluhan, dan kesopanan staf.

\section{PEMBAHASAN HASIL PENELITIAN}

Dari hasil penelitian diketahui bahwa responden wanita dan pria jumlahnya hampir seimbang yaitu 49\% pria dan 51\% wanita. Sedangkan dilihat dari segi usia, responden terbanyak adalah yang berusia antara 26-35 tahun (36\%), 17-25 tahun (25\%), 35-50 tahun (19\%), > 50 tahun (14\%) dan lainnya 6\%. Selain itu kebanyakan responden mempunyai latar belakang pendidikan S1 (55\%) dan SMA atau yang sederajat (34\%), S2 atau lebih tinggi dari S2 (8\%) dan sederajat dengan SMP (3\%). Mayoritas responden berprofesi sebagai pelajar/ mahasiswa (30\%), wiraswasta (28\%), 
pegawai/ karyawan (25\%), profesional seperti guru, dokter, dll. (8\%) dan lainnya 7\% serta PNS 2\%. Penghasilan responden terbanyak adalah kurang dari Rp 2.000.000,00 (30\%) dan di atas Rp 6.000.000,00 (29\%), Rp 2.000.000,00-Rp 3.999.999,00 (24\%) dan Rp 4.000.000,00-Rp 5.999.999,00 (17\%). Jadi dapat disimpulkan bahwa mayoritas responden yang suka makan di restoran dan cafe adalah para kaum muda dan profesional yang berasal dari kaum menengah ke atas.

Penelitian tahap kedua juga mengungkap perilaku pelanggan Surabaya khususnya saat mereka makan di sebuah restoran dan cafe. Dari 1337 responden yang terlibat, sebanyak 32\% responden menyatakan bahwa rata-rata dalam 1 bulan mereka makan di restoran/ cafe sebanyak 3-4 kali dan responden yang makan di luar lebih dari 6 kali dalam 1 bulan adalah sebanyak 28\%, 21\% responden makan antara 1-2 kali/ bulan sedangkan sisanya 19\% makan di restoran/ cafe sebanyak 2-6 kali/bulan. Adapun kegiatan makan di luar dilakukan paling banyak bersama dengan keluarga (47\%) dan teman (42\%), dengan rekan/ partner bisnis 10\% dan 1\% dilakukan sendiri. Lebih lanjut, sebagian besar responden (68\%) menyatakan bahwa rata-rata uang yang dikeluarkan setiap kali makan di restoran/ cafe adalah antara Rp 100.000,00 - Rp 499.999,00 (68\%), kurang dari Rp 100,000,00 (19\%), Rp 500.000,00 - Rp 999.999,00 (8\%). Dan di atas Rp 1.000.000,00 sebanyak 5\%. Dengan demikian dapat dikatakan bahwa mayoritas responden melakukan kegiatan makan di restoran atau cafe paling tidak seminggu sekali dan seringkali dilakukan bersama-sama anggota keluarga atau rekan bisnis dengan rata-rata pengeluaran antara $\mathrm{Rp}$ 100.000,00-Rp 499.999,00.

Hasil penelitian menunjukkan CSI dari masingmasing dimensi layanan seperti pada Gambar 3.

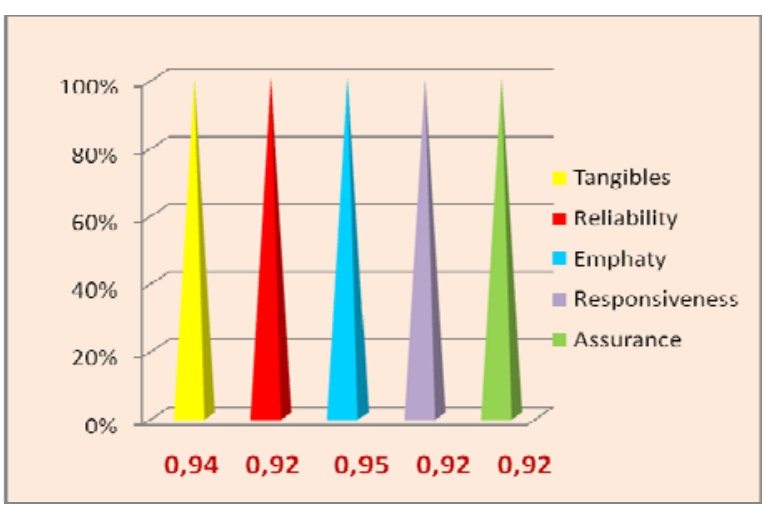

Gambar 3. CSI Lima Dimensi Kualitas Layanan

Dari gambar 3 terlihat bahwa di antara lima dimensi kualitas layanan yang diukur, dimensi empati (emphaty) merupakan dimensi yang meraih derajat pemenuhan kepuasan yang tertinggi, yaitu sebesar 0.95. Artinya, apa yang diharapkan oleh konsumen Surabaya terkait dengan kualitas layanan dari sisi empati dinilai paling dapat dipenuhi oleh pihak pengelola restoran/cafe dibandingkan dengan dimensi layanan yang lainnya. Peringkat kedua adalah dimensi fasilitas fisik (tangibles) dengan CSI 0,94. Sedangkan dimensi keterandalan (reliability), kecepat-tanggapan (responsiveness), dan jaminan (assurance) mempunyai nilai CSI yang sama yaitu 0,92. Nilai CSI rata-rata dari kelima dimensi kualitas layanan adalah sebesar 0,93 sehingga dapat dikatakan bahwa tingkat kepuasan pelanggan cukup tinggi karena mendekati 1.00 .

Dari 18 atribut layanan yang diukur, terdapat lima atribut layanan yang menurut konsumen menjadi pertimbangan utama dalam memilih restoran dan cafe di Surabaya yaitu: 1) Kebersihan restoran/cafe; 2) rasa/taste makanan dan minuman yang disajikan; 3) Kesopanan staf ; 4) Ketepatan penyajian makanan dan minuman; serta 5) keramahan staf dalam melayani konsumen. Hal ini nampak pada Gambar 4.

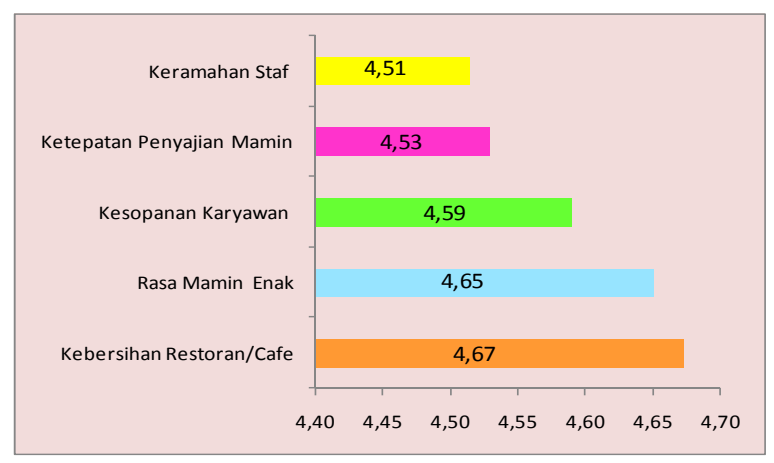

\section{Gambar 4. Lima Atribut yang Dianggap Paling} Penting

Selain itu juga diketahui bahwa kelima atribut layanan yang dianggap penting itu ternyata sudah mampu dipenuhi oleh pengelola restoran/ cafe meskipun kelima atribut layanan itu menduduki ranking/ urutan yang sedikit berbeda. Hal ini tampak pada gambar 5 dimana atribut pendongkrak kepuasan yang paling utama adalah 1) Kesopanan karyawan, 2) Kebersihan restoran/ cafe, 3) Rasa makanan dan minuman yang enak, 4) Ketepatan penyajian makanan dan minuman, dan 5) Keramahan staf.

Dari Gambar 4 dan 5 dapat ditarik kesimpulan bahwa sejauh ini para pengelola restoran/ cafe sudah mampu memenuhi apa yang diharapkan oleh konsumennya.

Lebih lanjut kinerja kualitas layanan restoran/ cafe dapat dilihat melalui Importance-Performance 
Analysis/Matrix yang menggabungkan nilai harapan konsumen dengan nilai kepuasan konsumen seperti pada gambar berikut ini.

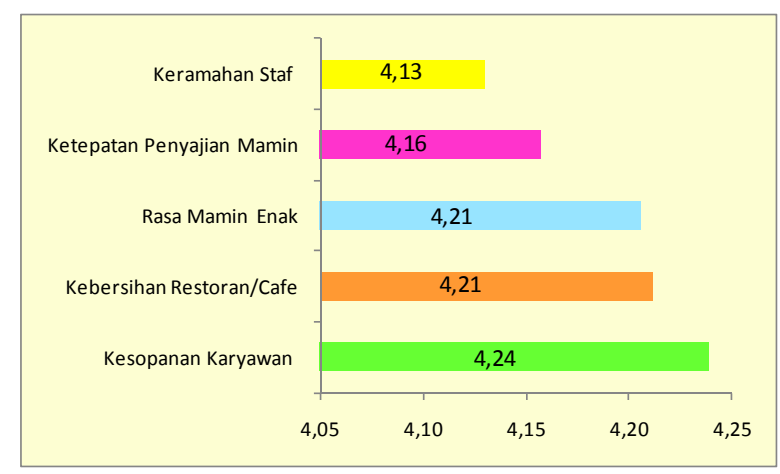

\section{Gambar 5. Lima Atribut Pendongkrak Kepuasan Tertinggi}

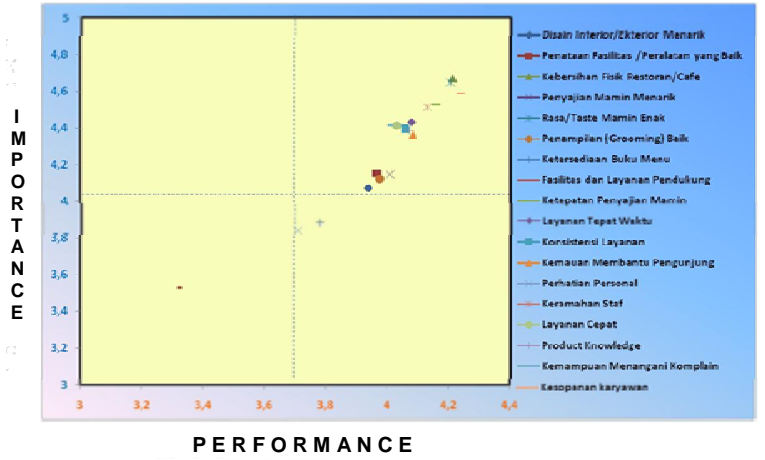

\section{Gambar 6. Importance-Performance Analysis/ Matrix}

Matriks ini menunjukkan bahwa dari 18 atribut layanan, 16 atribut layanan sudah mampu disampaikan dengan baik oleh pengelola restoran/ cafe karena atribut tersebut berada di kuadran kanan atas. Atribut-atribut ini dianggap penting oleh konsumen dan mampu dipenuhi oleh pengelola restoran/ cafe sehingga atribut ini harus tetap dikelola dan dipertahankan agar konsumen tetap merasa puas. Sedangkan 2 atribut yang lain yaitu ketersediaan buku menu dan perhatian personal yang dianggap cukup penting juga sudah mampu dipenuhi dengan baik oleh pengelola restoran/cafe. Atribut ini terletak di kuadran kanan bawah. Secara keseluruhan dapat dikatakan bahwa pengelola restoran/cafe sudah mampu menyampaikan kualitas layanan seperti yang diharapkan oleh konsumennya.

\section{KESIMPULAN DAN SARAN}

Hasil penelitian menunjukkan bahwa tingkat kepuasan pelanggan restoran dan cafe di Surabaya sangat tinggi atas kualitas layanan dari penyedia jasa yaitu sebesar 0,93 dan mendekati nilai 1,00. Pelanggan semakin menyadari pentingnya kualitas layanan selain produk makanan dan minuman. Produk makanan yang lezat dan minuman yang nikmat tidak akan mampu memuaskan pelanggan tanpa didukung kinerja dari staf/ penyedia jasa yang baik.

Dari 18 atribut layanan yang disampaikan semuanya sudah disampaikan dengan sangat baik sesuai harapan pelanggan restoran/cafe di Surabaya karena semuanya terletak di kuadran kanan dalam Importance Performance Analysis/Matrix. Dengan demikian dapat dikatakan bahwa bisnis restoran dan cafe di Surabaya sudah mampu memberikan kepuasan atas kualitas layanan yang disampaikan kepada pelanggannya. Hal ini tentunya juga harus tetap dikelola dengan baik oleh penyedia jasa untuk mempertahankan kesetiaan pelanggan. Kualitas layanan yang prima dapat menjadi salah satu strategi diferensiasi untuk dapat berkompetisi dalam bisnis.

\section{DAFTAR PUSTAKA}

Arnould, P., and Zinkhan. 2002. Consumer satisfaction. New York: The McGraw-Hill Companies, 614-653.

Gronroos, C. 2000. Service management and marketing: A customer relationship management approach. Second edition. Chichester: John Wiley \& Sons. Ltd.

Hartline, M. D., James G. M III and Daryl O. M. 2000. Corridors of influence in dissemination of customer-oriented strategy to customer contact service employees. Journal of Marketing Chicago: Apr. Vol.64. lss.2. 35. 16 pgs. http://proquest.umi.com/pqdweb?did=529813 45\&sid $=9 \&$ Fmt $=4 \&$ clientId $=72459 \& R Q T=3$ 09\&VName $=\mathrm{PQD}$

Hayes, B. E. 1997. Measuring customer satisfaction: Survey design, use and statistical analysis methods. Second Edition. Wisconsin: Quality Press.

Kotler, P., and Keller. K.L. 2006. Marketing management. 12edn. New Jersey: Pearson Education, Inc.

Lovelock, C., and Wirtz, J. 2004. Services marketing: People, technology, strategy. $5^{\text {th }}$ edition. New Jersey: Pearson Prentice Hall.

and Wright., L. 2002. Principles of service marketing and management. New Jersey: Pearson Education, Inc. 
Orilio, W. 2005. Moment of truth: Small gestures make a big difference in caring for customers. Nation's Restaurant News. New York: Mar 14, Vol.39. lss. 11. 19. 2 pgs. http://proquest. umi.com/pqdweb?did $=817451861 \&$ sid $=24 \& \mathrm{~F}$ $\mathrm{mt}=3 \&$ clientId $=72459 \& \mathrm{RQT}=309 \& \mathrm{VName}=$ $\underline{\mathrm{PQD}}$

O’Neill, M. A., and Palmer, A 2004. Importanceperformance analysis: a useful tool for directing quality improvement in higher education. Quality Assurance in Education. Bradford. Vol. 12. lss.1. 39. http://proquest. umi.com/pqdweb?did=650051981\&sid=1\&F $\underline{\mathrm{mt}=4 \& \text { clientId }=72459 \& \mathrm{RQT}=309 \& \mathrm{VName}=}$ PQD

Payne, A. 1993. The essence of service marketing. Hertfordshire: Prentice Hall International (UK) Ltd.

Sugiyono. 2004. Metode penelitian bisnis. Bandung: CV Alfabeta.
Sureshchandar, G.S., Chandrasekharan Rajendran and R.N. Anantharaman. 2002. The relationship between service quality and customer satisfaction - a factor specific approach. The Journal of Services Marketing. Santa Barbara. Vol. 16. lss. 4. p.363-390 http://proquest. umi.com/pqdweb?did=246322581\&sid $=6 \& \mathrm{~F}$ $\underline{\mathrm{mt}=4 \& \text { clientId }=72459 \& \mathrm{RQT}=309 \& \mathrm{VName}=}$ $\underline{\mathrm{PQD}}$

Zeithaml, V. A., and Bitner, M. J. 2003. Service marketing: Integrating customer focus across the firm. International Edition. New York: The McGraw-Hill Companies. Inc.

Bitner, M. J and Gremler, D.D. 2009. Services marketing: Integrating customer focus across the firm. International Edition. 5th ed. New York: The McGraw-Hill Companies. Inc. 